\title{
Philosophical Concepts of
}

\section{Professional Organization}

$\mathbf{M}^{2}$ $Y$ PURPOSE in appearing before you is to consider with you several questions about college and university librarianship. These are questions to which I do not have the answers. Apparently, you do not have the answers. If you had, you would have given them effective formulation in speech and in writing, and through organization and action. These remarks of mine would then be unnecessary. I may not have the answers, but I do have some opinions which I will gladly share with you. These are, then, my personal reflections upon our common problems.

\section{The American Library Association}

The American Library Association was founded in 1876 and is now well past its seventy-fifth anniversary. The object of the association, which I take to be the all-pervading purpose which has brought about its present state of maturity, is, according to its constitution: "to promote library service and librarianship." The key to the meaning of this phrase is the verb "promote." I have no quarrel with this definition of purpose.

The many services of ALA to the cause of libraries are beyond question. ALA tries to be all-inclusive. It offers the means for organization, discussion,

Mr. Lundy is Director of Libraries, University of Nebraska. This paper was presented at the meeting of the University Libraries Section, ACRL, Washington, D. C., June 24, 1959. cooperation, publication, and action. Through its divisions it reaches adult services, children's services, reference services, library education, and library administration generally. Through its member associations it provides for public, school, and state libraries, for hospital and institution libraries, and for our own group, the college and research libraries. Let us note in passing that autonomy and the benefits of isolation, dubious though they sometimes may be, are still preferred by libraries of law, theology, and medicine, and also by that widely diversified group of libraries which make up the Special Libraries Association.

Who are these more than twenty thousand librarians who make up ALA? By and large they are the practicing librarians. They are the individuals who hold more or less responsible assignments in a library of one kind or another. A library, I take it, is a collection of books brought together to serve a purpose. Libraries are not organized for profit. Library purposes are usually spelled out in terms of information, education, research, and recreation.

Membership may be held in ALA, and hence in any of its divisions or member associations, according to its constitution, by "any person . . . interested in library work ... upon payment of the dues provided for. ..." Anyone with six dollars in his pocket and an inclination to spend this into the treasury of ALA, may thereafter produce his membership card as evidence of the fact that he is a librarian. I cannot say that this 
is bad, either for the individual, or for the association. I have read somewhere that there are thirty-five or forty thousand individuals in these United States who are likely prospects for membership in our association, including the more than twenty thousand who have already joined. I should like to see all forty thousand in the membership. If ALA could do nothing other than point with pride to an occasional achievement of the nature and stature of the Library Services Act of Congress, it would still be worth more than its weight in dues to all the membership and to the entire country.

The point I wish to make here is that anyone may be a librarian, and literally anyone who will pay the dues may join the national association of librarians, attend and vote in its meetings, and otherwise take an active part in its work on a basis of parity with any and all other members. There are no minimum educational standards of any kind for being a librarian and for becoming a member of our association, nor are there any quantitative or qualitative standards of performance in the job of librarian. Literally, a collection of fifty or a hundred books, housed in the corner of the village grocery store, or in the county court house, may be designated a library, and the local citizen who sits in charge one or two afternoons a week, a librarian. I am not sure that this is as it should be. Such circumstances as those I describe are fairly numerous and appear to influence and condition the apathy and indifference with which the taxpaying public sometimes locks upon us and our work. An adequate income for our association is a most essential consideration, of course, but it might be well to have another look at the fact that at present the ability and willingness to part with six dollars annually is the only real and effective requirement for membership in ALA. Not even the six dollars is necessary for designation as a librarian. Almost anyone may set himself up as a librarian, in the public's understanding, and he does not have to pay dues to anything.

These remarks are addressed specifically to college and university librarians, and they are literally intended only for college and university librarians. I sense that I am on insecure ground when I imply a sweeping criticism of ALA. Within its means this organization has accomplished great things in the interest of providing more books to more people in the United States and abroad. If all of us in this room now had a free hand in organizing the present ALA membership of more than twenty thousand individuals, I am not as all sure that we would come up with something different that would be as effective generally as what we have had. I am not proposing another study of reorganization. Good minds within the membership have already taken ALA through several reorganizations during our lifetimes. What I have in mind as our basic problem actually may not very closely relate to the present organization of ALA.

\section{College and University Librarians}

To put the matter bluntly, I am concerned about the definition and the organization of the entire group of college and university librarians. To be more specific, I am concerned about their lack of definition and organization. The larger aspects of all librarianship in America, as represented in the total ALA, can easily take us too far afield, instead of leading us to specific and helpful solutions for our special problems. We college and university librarians need to look at our own problems, and there are many! Our problems are going to increase in number and in complexity as college enrollments rise from their present three million to more than five million students-and all this by 1965 , 
it is said. Nor will all of these major problems face all of us in equal terms. The swelling enrollments of college students on the campuses of several large state universities are posing library problems that at times seem overwhelming. Do you think that we can turn our backs upon these problems of organization and service? I do not think so! Nor do I think that we can solve all of our problems individually and alone on our separate campuses, although we may have to try. It seems clearly apparent to me that we must improve our opportunities for working together. We cannot always expect to go forward effectively, serving the best interests of the masses of students who come to us for a higher education, and the interests of our faculties as well, unless we are willing to face some of the shortcomings and omissions in our present activities. We must plan continuous, and perhaps radical, improvement in the collective organizational environment within which we are working.

There is, as you know, a steering committee for this ACRL section of university librarians and this committee has, during the past two years, held several spirited discussions of the problems of professional organization. I am a member of this steering committee and I have its permission to be as frank with you as I may wish.

\section{ACRL}

ACRL has many accomplishments to its credit. Perhaps the most evident of these is the excellent journal, College and Research Libraries, published continuously since 1939; and also, of more recent origin, the $A C R L$ Monographs. It is not appropriate here to list and describe the association's many other activities, such as subsidies for college book collections, college and university library surveys under ALA sponsorship, and the many outstanding program meetings. Special mention should be made of the many courtesies and services coming directly from the office of the ACRL executive secretary.

But the fact remains that when the Association of American Universities' Commission on Financing Higher Education produced its studies in the early part of the 1950's and levied specific criticisms against librarians on university campuses, there appeared to be no effective means to bring this matter under continuous study within ACRL. There was, of course, a program on the subject, and the commission's executive director, John D. Millett, faced the librarians in person. It remained, however, for a private organization outside ALA, known as the Association of $\mathrm{Re}$ search Libraries (ARL), to organize the Monticello Conference on this subject. Parenthetically, can you even imagine where we might bring this same problem under study now within the newly reorganized ALA?-somewhere within the vast domain of the Library Administration Division, no doubt, in a committee composed of assorted librarians from many and diverse types of libraries! I do not mention the incident of the Monticello Conference and the causes which produced it as evidence of neglect on the part of the collective body of university librarians. Through the ACRL program meeting and the ARL discussions at Monticello and the many more localized discussions of the same problem, it is evident that the questions raised by the Commission on Financing Higher Education were adequately answered, at least sufficiently at that time.

On many occasions I have asked my colleagues in university librarianship where the major problems of university libraries do actually come into focus, for discussion and analysis, within ALA. I have in mind such problems as those pertaining to the framing and management of a budget, cooperative buying, 
the recruitment and direction of personnel, the status of the academic librarian, and many others in the realm of administration which are over and beyond those having to do with collection-building and bibliographical control. The answers I get are usually vague. Committees scattered throughout ALA can be mentioned in connection with some few of the specific points at issue. But there is no real "home base"-is there?-within the whole ALA for the problems of university libraries and their librarians.

It is true that many of these problems have points at issue in common with similiar ones in other library environments: in the public library, the special library, the county or state library, or the Library of Congress. It is also true that the problems of university librarians are uniquely conditioned by their own environment, which is the university campus. The special factors on the campus are the faculty, the students, and the governmental structure of a university. There have been many occasions on which I have wished fervently that I could take some of my problems into discussion with colleagues in university librarianship, in order to put them under systematic study by committees composed of other university librarians with similar problems and with like interests.

The ACRL University Libraries Section has produced an unbroken series of excellent papers and speeches on college and university library topics. I can only hope that I am not, at this moment, damaging this fine record. But, for the most part, the association, and this section in particular, has been content with papers and speeches. It is in no real sense a "home base" for the problems of university libraries and their librarians. I cannot help adding that under the present plan of reorganization within ALA the ACRL University Libraries
Section is actually faced with the prospect of going out of existence altogether, except as a polite token of recognition may be extended to it in the programs of the annual summer conference. All of the basic studies of library activities are now being assigned to the activity divisions of ALA. There is a real danger, I do believe, in discarding the college or university campus as a conditioning factor of the utmost importance in relation to some of our problems.

What I am saying is that ACRLdespite its publications and fine program meetings and its occasional efforts to grapple with other matters-is not the strong and all-embracing national association of college and university librarians that it might well be, or, in my opinion, that it should be. There has been reason to believe, on some occasions, that many of our university librarians do not want a strong national association within their ranks, or do not recognize the potential of strength that might be developed in such an organization for studying contemporary problems of library policy and administration on the campus. I cannot agree with these few that each of us is essentially in business for himself. But I do not believe that this attitude has been the determining factor in opposition to the development of such an association. There are two such factors, however, to which we should give our attention.

\section{The Association of Research Libraries}

The first of these is the Association of Research Libraries. The nature and purpose of this association are frequently misunderstood. ARL, as it is called, was founded in 1931. Its object is "by cooperative effort, to develop and increase the resources and usefulness of the research collections in American libraries." Essentially, what this has meant through three decades of continuous effort is that ARL has taken a very ef- 
fective interest in collection-building and in bibliographical controls. I know of no worthier purposes to which a group such as ARL might address itself and, as you well know, its accomplishments have been many and highly significant.

There appears to be a curious lack of effective communication between ARL and ACRL. This is true despite the fact that a majority of the participants in the meetings of ARL are also members of ALA, and customarily participate in the meetings of ACRL's University Libraries Section, and in a few other ALA activities. There are a few ARL participants who merely look briefly in upon the early part of the ALA week and then go home. These few are chiefly the history professors in the ARL. Usually they are not those who have given years to the formal graduate study of librarianship as well as to its practice.

ARL is an organization of libraries, and not of individual librarians. Each member institution is entitled to be represented by one individual at meetings of the association, and this individual is nearly always the director of the library. The membership of ARL has for many years approximated fifty institutions, or slightly fewer. There is, to be frank with you, no magic in the number fifty. There are a few librarians among the present membership of ARL who believe that the association could more efficiently devote itself to its purposes and projects if its membership could be reduced to the twenty-five or so institutions who thus far have really exercised leadership in collection-building among our research institutions. However attractive this view may be in theory, there has at no time been a majority willing to vote in its favor. On the other hand, there are also a few librarians among the present membership who believe that the number of member institutions might very well be increased to seventy-five- perhaps even to one hundred-in order that the association might be truly more representative of the research libraries of America than it now is; also in order that it might broaden the scope of its interests and the activities of its committees. This proposition, too, has failed to command a majority vote. And so the membership remains for the present stabilized at approximately fifty.

How are these fifty memberships determined? That is an interesting question! In recent years, at intervals of five years, ARL has had a critical look at its membership. It has, on those occasions, collected and scanned a quantity of data concerning present members and applicants for membership. At no time, to my knowledge, has there been an actual agreement on the quantitative or qualitative data that might be taken as prerequisite to actual election. The voting process is, therefore, a subjective one. Rarely has a member been dropped! Each of those few occasions has involved a good deal of emotional soul-searching among "the brothers." Only occasionally is a member added, as some of you know only too well.

In its organizational structure, ARL is essentially a private club. I am only too well aware that for having divulged that secret I may be severely disciplined, or thrown out of its membership-though not, I hope, the institution which I have been representing! Further evidence of what I have just said about a private club is to be found in ARL's governing body, an advisory committee of five which is self-perpetuating. When a member of this committee has served his term of several years, and during his last year on the committee has also presided at ARL meetings, this committee then meets to decide who among the total membership shall succeed the retiring member. This is in no sense an election and the subsequent approval voted by the association as a whole is purely a formality. 
I am not in any way personally opposed to this arrangement for the government of the club. There are many occasions in American political and professional life when one is strongly tempted to conclude that a benevolent despotism, or a benevolent oligarchy, may sometimes be the best of all forms of management. The open question resides in the word "benevolent." Sometimes this concept has a short life. This idea reminds me that prominently upon the face of the magnificent state capitol building in Lincoln, Nebraska, there is carved the following legend: "The Salvation of the State Is Watchfulness in the Citizens." I have heard this casually interpreted as meaning: "You have to watch these rascals!" In order that you may fully appreciate the beauty of our governmental climate in Nebraska, I should also like to share with you the companion inscription on the opposite side of the building, which reads: "Political Society Exists for the Sake of Noble Living."

The essential point to my remarks about ARL is simply that this is a private and somewhat exclusive organization which does excellent work in the limited field of librarianship to which it has addressed itself. Further, that ACRL does a disservice to all college and university libraries when it mistakenly defers to ARL, or to any other organized group of librarians outside its own ranks, in undertaking the study of problems that deserve its immediate attention. Instances of such mistaken deference could be mentioned between ACRL and ARL and also between ACRL and the ALA activities divisions. If $\mathrm{ACRL}$ is to be governed entirely by administrative fiat from other agencies of this unwieldy holding corporation, it will shortly go out of business. In fact, you might well consider if this is not what is actually happening now! Even if you are willing to grant to ARL all primary interest and initiative in collection-building and bibliographical control among research libraries, there will still remain several problem areas of special interest to college and university libraries as a group. These problem areas concern our libraries in the environment of higher education, and irrespective of whether the point at issue may be their management and administration, the quality of the staff, the physical plant, the place of the library in the academic community, or some other equally important phase of the institution's operation.

\section{Professional Consciousness}

The underlying cause of our predicament is a lack of professional consciousness among us. My barber talks to me frequently about the problems of his "profession." Some of his conversation pertains to the "tricks of the trade" which have to do with scissors and comb, tonics and lotions, and sanitary regulations. Occasionally he mentions hours of work, union dues, and the lone barbers who won't join up. At the other end of the scale of occupations that either have professional status, or aspire to have it, are the medical doctors-the M.D.'s. Here, I believe, is a truly professional group, in terms of standards of training and performance, ideals of service, the organization of medical care through clinics and hospitals, and the improvement and guidance of all these through the activities of local and national medical societies. Underlying good medical care and effective organization for this purpose among doctors is their firm concept of basic training. No one practices medicine without having completed medical training, and in a school accredited for that purpose. Did you ever hear of a one-semester doctor, or a oneyear doctor? No, and you never will! $\mathrm{He}$ either completed the medical course, or he didn't! The same, be it noted, is true of the law! No one in these days 
can aspire to practice law by simply "reading some law," although this appears to have been common practice seventy-five years ago.

Between these two extremes, the doctor and the barber, where do we librarians stand? Are we really trying with discernible effect to take our place among other recently emerging professions; for example, alongside the dentists and pharmacists, the social workers and the clinical psychologists? Are we strengthening the standards of our professional work as librarians and also the basic training we consider to be prerequisite to it? No, actually, I think not!

It is true, to be sure, that during the past thirty years the principal library schools have become associated with colleges and universities. The old Certificate in Librarianship has been abolished and the Master of Arts (or Master of Science) degree has been standardized. The Doctor of Philosophy in Librarianship has emerged. The Ph.D. degree in librarianship may have arrived just "in the nick of time." There has been a noticeable trend among college and university presidents in recent years to use the head librarianship of the academic institution as a convenient place to store one or more of the oversupply of individuals trained essentially to teach history, or English, or some other subject. May I take it simply as evidence of the acute shortage of librarians trained at the top level that we do not observe the reverse of this phenomenon: the appointment of doctors of philosophy in librarianship to be full professors of history and chairmen of their departments? When I referred to the standardization of the Master's degree in librarianship a moment ago, you must realize, of course, that I was being somewhat facetious. A few of our recent graduates in librarianship - a small few, fortunately-seem to have no clear notions at all as to what is expected of them on the job.
The medical doctors do not solve their complicated problems of effective organization by blanketing in all the individuals who in any way relate to the practice of medicine. You will not find in the membership of the American Medical Association, or in the local county medical society, all of the nurses, laboratory technicians, and hospital administrators - to say nothing of receptionists and office help, custodians and ambulance drivers! Quite the contrary is true! To the extent that these various groups need organization in order to sustain and improve their work, the doctors encourage them to develop their own organizations, with or without close supervision.

Librarians, on the other hand, have an evangelical approach to organization. In effect and without pausing to reason what for, we cry: "Come one and come all! Pay your six dollars and join up!" We college and university librarians are no exception. We live and work in academic communities populated with highly trained men and women. The library is an essential part of the complex process of higher education and research. We sorely need enforceable standards of training and performance.

What happens to the college and university librarians who do attend the annual summer conference of ALA? Here, at least, you would join me in expecting to find a large number of these men and women meeting together in a variety of close-knit ways to study and to resolve some of their common problems. I repeat here that the academic community in which they work at home provides an essential bond-one which should not lightly be ignored or dissolved. There is little good for most of us in the notion that our special interests can just as well be scattered throughout the entire rank and file of ALA. This very tendency within ALA has long been an effective and permanent barrier between our academic group, on the one hand, and the 
legal, medical, and "special" librarians on the other hand-all of whom, for very obvious reasons, prefer to meet together in their own restricted groups, for the sake of close association and intensive discussion.

University librarians have contributed a degree of leadership to ALA which is entirely out of proportion to their actual numbers within its total membership. This is, of course, a credit to the university librarians! Where do you find them during the course of this conference week? You will find them scattered throughout ALA, giving speeches, conducting meetings, attending numerous committees, and behaving generally like the prima donnas and professional monologists which most of them habitually are.

You may have noted that this particular meeting of university librarians was scheduled unhappily, but without protest, at $4: 30$ in the afternoon-the deadliest hour of any conference day! If you will look around you will also notice that many of the participants in last Sunday's meeting of the Association of Research Libraries have already gone home. Last Monday afternoon, many of you may have attended the program meetings of either the Library Organization and Management Section of the Library Administration Division, or of the Resources and Technical Services Division, both scheduled at the same hour. The content of the latter meeting concerned that important and far-reaching new development known as "Cataloging in Source." Again, unhappily, but apparently without protest, the leadership of some twenty research libraries in the Middle West was precluded from attending either meeting because of a wholly unnecessary conflict with the advisory group of the Midwest Inter-Library Center.

My point, with reference to all of us, college and university librarians alike, is that such dissipation and scattering of our energies and efforts have become habitual with us. We do need a national association of college and university librarians. We need a strong, hardworking, and effective organization for the study and solution of our major problems on the academic campus. We need an organization whose purposes and whose conferences can enjoy a high degree of preference among the members, over all the distractions and dissipations that are customarily thrown in our way. And we need, above all, to make this a professional organization-not simply a collection of all the individuals in the community who happen in any way to be involved in the work of the campus library. We need these things-but we have never had them-and we most certainly do not have them now!

\section{Attributes of a Profession}

One more word on the idea of a profession. Among the attributes of a profession we note the possession of a distinctive body of special knowledge and a superior skill in its use, held in common by its members, under the compulsion of a sense of high personal responsibility. We note a recognition of its obligation to extend this body of knowledge by research and scientific observation of practice, with a sharing of the results. We note the motivation of social duty and honorable service, preferred above personal gain. We note established means for the adequate education of its novitiates. We note standards of qualifications based upon training and competency, character and ethical perception and conduct. And we note a group organization with national standing concerned with public interest.

Some of these we college and university librarians have achieved. We have a distinctive body of special knowledge. If you do not believe this, will you please take time to look carefully into the content of the library school libraries at the Universities of Chicago or Illinois, to 
mention only two. We have a publication program for recording and sharing the results of our research. If we are not strongly motivated by social duty we work in vain, for private profit is nowhere in evidence. We have the means for adequate education in our several library schools, some of them of excellent reputation. But we have almost entirely avoided setting standards of qualification based upon training and competency. Despite our several library schools of quality and their graduate training programs, we still do say "anybody is welcome to be a librarian," and we mean literally "anybody." It may be for this reason alone that we college and university librarians have not achieved a group organization with national standing.

We college and university librarians are an incomplete and badly scattered fragment of ALA. ARL, standing separate and apart, is but a very small part of all of us. It is limited in membership and in scope and is in no way an adequate substitute for a strong national association composed of the professional staff members of all college and university libraries. ACRL is at present a somewhat frustrated and deteriorating division of the total ALA.

Last year your steering committee of this University Libraries Section undertook to submit ten or twelve projects upon which it would like to go to work now. It was told at once that all but one or two of these proposals appeared to be "out of bounds" for the section in the reorganized ALA, since they were more properly assignable to the committees and sections of the activities divisions of ALA. At this point of transfer and reassignment, let me remind you, the academic community entirely loses its identity, since the activities divisions derive their memberships from libraries of every possible size and type-except, as we noted, from legal, medical, and "special" libraries, which have remained entirely apart and which, apparently, are wiser in such matters! Such actions, it seems to me, are based upon a fundamental and tragic fallacy in our total organization.

In support of these remarks I offer you my own experiences of thirty years of continuous membership in ALA and also those of the past fifteen years during which I have been the director of a typical state university library of medium size. Although I have written many papers for our journals, made speeches on a variety of occasions, and am generally regarded as an inveterate conventiongoer, I must admit that the quest for identification for the academic library which I now direct and represent, and for the solution of some of its many problems, is becoming increasingly difficult.

Surely, we can do better! Most sincerely, I hope that we will-and soon!

\section{Eastern Librarians}

The Forty-Fifth Annual Conference of Eastern College Librarians will be held on November 28 at the Harkness Academic Theatre, Butler Library, Columbia University. The conference's theme is "Where Shall the Academic Library Find Its Leadership?" Speakers include Robert E. Moody, John F. Harvey, William S. Dix, and Louis Shores. The morning program will start at 10 a.m., with Rev. John H. Harrington presiding. John Frost will preside at the afternoon session. Chairman of the Program Committee is Wayne Shirley, librarian of Finch College. No advance registration is necessary. 